\title{
Analysis and advanced characterization of municipal solid waste vermicompost maturity for a green environment
}

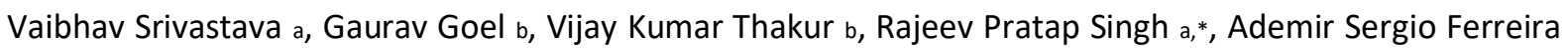
de Araujo c, Pooja Singh d

a Department of Environment and Sustainable Development, Institute of Environment and Sustainable Development, Banaras Hindu University, Varanasi, India

b School of Aerospace, Transport \& Manufacturing, Cranfield University, United Kingdom

c Agricultural Science Center, Federal University of Piaui, Teresina, PI, Brazil

$\mathrm{d}$ Department of Science, Institute of Computer Science and Technology, SHEPA, Varanasi, India

\begin{abstract}
Rapid demographic expansion along with increasing urbanization has aggravated the problem of solid waste management. Therefore, scientists are seeking waste management methods that are eco-friendly, cost effective and produce immediate results. In the developing world, municipal solid waste (MSW) contains mostly organic substances, therefore vermicomposting could be a better and cost-effective option for waste management. In this study, vermicomposting of organic portion of MSW with cow dung (additive) was performed using Eisenia fetida. The results showed significant $(p<0.001)$ decline in $\mathrm{pH}(13.17 \%)$, TOC (21.70\%), C: N (62.53\%) and C: P (57.66\%) ratios, whilst total N (108.9\%), P (84.89\%) and K $(21.85 \%)$ content increased $(p<0.001)$ in matured vermicompost. Different enzymatic activities declined during termination phase of vermicomposting experiments with maximum decrease of $41.72(p=0.002)$ and $39.56 \%(p=0.001)$ in protease and $\beta$-glucosidase, respectively. FT-IR, TGA, DSC and SEM studies suggested that final vermicompost was more stabilized as compared to initial waste mixture, characterized by reduced levels of aliphatic materials, carbohydrates and increase in aromatic groups possibly due to biosynthesis of humic substances. Both, the conventional (physicochemical and enzyme activity) and advanced techniques depict maturity and stability of the ready vermicompost. However, FT-IR, TGA, DSC and SEM were proved to be more promising, fast and reliable techniques over conventional analyses.
\end{abstract}

Keywords: Municipal solid waste (MSW); vermicompost; Eisenia fetida; spectroscopy; thermogravimetry (TG); differential scanning calorimetry (DSC) 


\section{Introduction}

Prodigious population growth and urbanization along with techno-economic development are responsible for continuing expansion of cities. It has put additional pressure on infrastructural services and food security across the globe (Srivastava et al., 2015). These factors affect the consumption pattern of the society that has been accompanied by high amount of solid waste generation and its compositional changes (Khan et al., 2016). As stated in the World Bank report (2018), the annual rate of municipal solid waste (MSW) generation were 2,010 million tonnes in 2016, which is projected to reach 3,400 million tonnes by 2050. A huge quantum of global waste $(33 \%)$ usually finds its way to open dumping sites which is still the preferable method for waste disposal in low income countries (93\%). About $75 \%$ of the solid waste is open dumped in South Asia, followed by Sub-Saharan Africa (69\%) and Middle East and North Africa (52.7\%). In low- and middle-income countries, the quantum of organic fraction of waste is exceeds $50 \%$ which upon degradation produces various noxious gases (e.g. $\mathrm{CH}_{4}, \mathrm{CO}_{2}$, and $\mathrm{H}_{2} \mathrm{~S}$ ) and leachate at dumpsites that poses serious environmental and health hazards (Goel et al., 2017; Sharma et al., 2018). Therefore, it is imperative to identify simple techniques for solid waste reduction and stabilization with low operational and maintenance cost that would also help in achieving the environmental and public health standards (Srivastava et al., 2016; Goel et al., 2017). Additionally, segregation of organic fractions will lead to less amount of waste reaching dump sites.

Nowadays, agricultural application of organic waste is getting recognition across the globe due to high proportion of organic matter and nutrient rich profile, which also reduces dependency over inorganic fertilizer (Srivastava et al., 2016). However, processing of these organic wastes is obligatory prior to its agricultural utilization (Srivastava et al., 2018). Recently, vermicomposting of organic waste has received research attention globally and is considered as promising and sustainable technology to reuse organic wastes. Vermicomposting is a nonthermophilic exercise which transform complex organic materials into a nutrient rich stabilized product through bio-oxidation (Srivastava et al., 2015; Lim et al., 2016). In vermicomposting, degradation of organic waste materializes through gut microbes of earthworm and results in a stable and mature vermicompost (Lim and Wu 2015; Lim et al., 2016). Stable vermicompost is humus like material, having nutrient rich profile and plant growth hormones which can augment soil physico-chemical and microbial properties and enhance plant growth (Srivastava et al., 2016; Bhat et al., 2017).

The agricultural use of organic waste manure produced through vermicomposting is one of the possible approaches to restore soil productiveness and organic waste management (Ostos et al., 2008; Bhat et al., 2016). However, it is essential to determine vermicompost stability before its 
agricultural applications that may otherwise cause phytotoxicity (Aamir et al., 2010). Stability is directly linked to biological activity of vermicompost and is dependent on degree of biodegradation achieved during vermicomposting process, while maturity is associated to phytotoxin free final vermicompost (Wang et al., 2004). In addition to the alterations in physico-chemical and enzymatic activities, the stability and maturity of vermicompost can also be determined by spectroscopic and thermogravimetric methods (i.e. fourier transform infrared (FT-IR) spectroscopy, differential scanning calorimetry (DSC) and scanning electron microscopy (SEM)) ( Amir et al., 2010; Ravindran et al., 2013; Hussain et al., 2015; Lim and Wu, 2016; Soobhany et al., 2017; Khatua et al., 2018). Previous studies have shown that FTIR, TG and DSC analyses are among the most promising, fast and reliable techniques for characterizing heterogeneous organic material, which provide a complete information on compositional, functional and behavioral properties of samples (Kumar et al., 2013; Ouaqoudi et al., 2015; Soobhany et al., 2017). Likewise, SEM analysis gives information on morphological structure of vermicompost that validates maturity and stability of product (Rajpal et al., 2014; Bhat et al., 2015; Hussain et al., 2016).

Earlier studies on vermi-stabilization of different organic wastes focused on changes in physico-chemical properties ( Suthar et al., 2015; Hussain et al., 2016; Arora and Kaur, 2019), enzyme dynamics (Yadav et al., 2015; Villar et al., 2016; Sudkolai and Nourbakhsh, 2017) and evaluation of vermicompost as soil organic amendments ( Lakhdar et al., 2012; Weber et al., 2014; Srivastava et al., 2018). To date very limited studies are present which include both traditional and advance techniques to evaluate stability and maturity of organic waste through vermicomposting. Also, the information of the appropriateness of vermitechnology for transmuting organic portion of MSW into humic substances and qualitative analysis of vermicompost is still in its infancy. Therefore, in this study multiple techniques were used to evaluate stability and maturity of vermicompost with following objectives: (a) analysis of the physico-chemical changes during vermicomposting process of organic portion of MSW mixed with cow dung; (b) evaluation of enzymatic dynamics in initial feed material and final vermicompost; (c) compositional, functional and structural changes in initial feed material and final vermicompost using FTIR, TGA, DSC and SEM.

\section{Material and methods}

2.1. Experimental setup, vermicomposting of municipal solid waste, and quality control 
The experiment was carried out at the test site of Institute of Environment and Sustainable Development (IESD), Banaras Hindu University, Varanasi, during October to December 2016. The mean monthly maximum temperatures ranged between 21.2 to $32.2^{\circ} \mathrm{C}$ and mean monthly minimum temperatures between 11.3 to $21.0^{\circ} \mathrm{C}$ during the study period. Total precipitation was recorded to $5.4 \mathrm{~mm}$ while mean monthly maximum and minimum relative humidities varied from 76.4 to $93.2 \%$ and 45.0 to $68.0 \%$, respectively. The substrate was prepared by mixing dried chopped organic portion of municipal solid waste (OPMSW) (containing vegetable, paper, flower, leaf litter etc.) and cow dung (CD) in ratio of 60: 40 (w/w). The OPMSW is heterogenous and complex in nature having various components with different physico-chemical properties. Moreover, microbial activation is essential to initiate biodegradation of OPMSW. Many previous studies suggest that CD is a suitable bulking material for making a microbially active substrate with different organic waste components during the vermicomposting process (Paul et al., 2011; Suthar et al., 2015; Srivastava et al., 2018). Apart from that, CD addition is well known to improve the stabilization process of different waste stuffs and increase of the earthworms' survival rate (Lim et al., 2016; Yuvaraj et al., 2018). Therefore, CD appeared to be a suitable bulking material with OPMSW for preparing the substrate. Substrate material was pre-decomposed for 3 weeks and thorough turning was performed after each week. The moisture level was maintained by spraying water during this period. Pre-decomposition was performed to attain thermal stability and the removal of volatile toxic substances (Srivastava et al., 2015; Arora and Kaur, 2019; Sharma and Garg, 2019). Also, it helps in making the substrate material palatable to the earthworms and breaking oily and fatty substances in the feed material prior to the earthworm inoculation (Sharma and Garg, 2019). The physico-chemical characteristics of pre-decomposed CD, OPMSW and waste mixture are presented in Table 1. After pre-decomposition; healthy, equal sized and nonclitellated 25 earthworms (Eisenia fetida) were hosted in plastic containers of 2 litre capacity containing 1000 gm of mixed substrate. The setup was established in triplicate. The moisture level in the substrate was kept at $70-80 \%$ by sprinkling fresh water on alternate days. The samples were collected from all the three established vermicomposting units in triplicate. These sub-samples from all three vermicomposting units (total 9 nos.) were mixed to form single composite sample to maintain homogeneity and to make a representative sample. The representative sample was divided into three parts (for initial and final sampling). The first part was air-dried in shade at room temperature till stable mass was achieved. This was followed by physico-chemical analyses. Second part was air dried for 3-4 hours in shade at room temperature to remove excess moisture content attained during vermicomposting and 
refrigerated in the plastic vials below $4^{\circ} \mathrm{C}$ to keep samples stable until further instrumental analyses (Ernesto et al., 2009; Wu et al., 2011; Kumar et al., 2015). The third part was not airdried and directly kept in plastic vials at $4{ }^{\circ} \mathrm{C}$ for different enzyme analyses. The physicochemical analyses were performed at every two-week interval throughout the vermicomposting operation, while different instrumental, and enzyme activity were measured in initial substrate and final vermicompost samples.

Quality control was assured by the use of analytical grades (AR) chemicals, standard protocols and operating procedures, and calibration with standards. IBM Statistical Package for the Social Sciences (SPSS) version 16 (Illinois, USA) was applied for all the statistical analyses. Sigma Plot version 10 software was used for all the graphs related to different enzyme analysis, while Origin 9.1 software was used to plot the graphs for spectroscopic and thermal analyses.

Table1 Initial physico-chemical properties of pre-decomposed CD, OPMSW and waste mixture (mean $\pm \mathrm{SE}, \mathrm{n}=3$ )

\begin{tabular}{llll}
\hline Parameters & \multicolumn{3}{l}{ Pre-decomposed material (3 weeks) } \\
\cline { 2 - 4 } & CD & OPMSW & Waste mixture \\
\hline $\mathrm{pH}$ & $7.71 \pm 0.003$ & $8.58 \pm 0.003$ & $8.35 \pm 0.01$ \\
$\mathrm{EC}(\mathrm{mS} \mathrm{cm}-1)$ & $1.43 \pm 0.01$ & $1.29 \pm 0.01$ & $1.27 \pm 0.01$ \\
$\mathrm{TOC}(\mathrm{g} \mathrm{Kg}-1)$ & $425.1 \pm 0.50$ & $509.8 \pm 4.10$ & $465.9 \pm 0.99$ \\
$\mathrm{TKN}(\mathrm{g} \mathrm{Kg}-1)$ & $6.24 \pm 0.12$ & $10.54 \pm 0.17$ & $8.06 \pm 0.12$ \\
Total P $(\mathrm{g} \mathrm{Kg}-1)$ & $5.41 \pm 0.25$ & $8.86 \pm 0.12$ & $7.81 \pm 0.12$ \\
Total K $(\mathrm{g} \mathrm{Kg}-1)$ & $10.06 \pm 0.29$ & $13.89 \pm 0.01$ & $13.27 \pm 0.12$ \\
$\mathrm{C} / \mathrm{N} \mathrm{ratio}$ & $68.16 \pm 1.41$ & $48.40 \pm 0.94$ & $57.81 \pm 0.95$ \\
$\mathrm{C} / \mathrm{P} \mathrm{ratio}$ & $78.97 \pm 3.80$ & $57.54 \pm 0.72$ & $59.69 \pm 0.83$ \\
\hline
\end{tabular}

\subsection{Physico-chemical analyses of vermicompost}

Measurements of electrical conductivity (EC, Model 303, Systronics, India) and pH (Model 802 , Systronics, India) were achieved with suspension of vermicompost in distill water (ratio of $1: 10(\mathrm{w} / \mathrm{v}))$ that has been mixed thoroughly for $30 \mathrm{~min}$ with subsequent filtration via filter paper (Whatman No. 1). The total organic carbon (TOC) was estimated by 'dry combustion method' as described by Nelson and Sommers (1982) (Appendix S1). Total nitrogen (N) content of samples was ascertained using automatic $\mathrm{N}$ analyzer (Model KEL PLUS, India) by applying Kjeldahl method (Jackson, 1975). Total phosphorus (P) was worked out using procedure prescribed by Allen et al. (1974), and potassium (K) content was deduced by using flame photometric method. Analysis of variance (ANOVA) was implemented to decide the significant differences between different time intervals for the observed physico-chemical characteristics of vermicompost using Duncan's multiple range test (DMRT) post hoc test. 


\subsection{Enzyme activities}

The urease enzyme activity was ascertained by ammonium released. Measurement were conducted after nurturing the samples ( $5 \mathrm{~g}$ fresh weight) with urea solution $(0.08 \mathrm{M})$ for 2 hours at $37{ }^{\circ} \mathrm{C}$ along with $\mathrm{KCl}$ solution $(1 \mathrm{~N} \mathrm{KCl}$ in $0.01 \mathrm{~N} \mathrm{HCl}$ ), at $690 \mathrm{~nm}$ (Kandeler and Gerber, 1988). The acidic phosphomonoesterases activity was assessed by the release of p-Nitrophenol (PNP). For this purpose, samples (1 g fresh weight) were incubated $\left(1 \mathrm{~h} @ 37^{\circ} \mathrm{C}\right)$ in presence of p-nitrophenyl phosphate $(0.025 \mathrm{M})$ and measurement at $400 \mathrm{~nm}$ (Eivazi and Tabatabai, 1972). The dehydrogenase enzyme activity was inferred by evaluation of the rate of decrease of triphenyl tetrazolium chloride (TTC) (3\%) to triphenyl formazan (TPF). Quantification was done at $485 \mathrm{~nm}$ after incubation at $37{ }^{\circ} \mathrm{C}$ for 24 hours (Casida et al., 1964). Estimation of protease activity was accomplished by measuring tyrosine extricated. For this, samples $(1 \mathrm{~g}$ fresh weight) were incubated $\left(2 \mathrm{hrs} @ 50{ }^{\circ} \mathrm{C}\right)$ in presence of sodium caseinate $(2 \%)$ and with Folin-Ciocalteu reagent, at $700 \mathrm{~nm}$. The $\beta$-Glucosidase activity was analyzed by determining p-Nitrophenol (PNP). This was determined by incubating $\left(1\right.$ hour @ $\left.37^{\circ} \mathrm{C}\right)$ samples $(1 \mathrm{~g}$ fresh weight) using p-Nitrophenyl $\beta$-D-glucopyranoside (PNG, $0.025 \mathrm{M}$ ), at $400 \mathrm{~nm}$ (Eivazi and Tabatabai, 1988). Paired Student's t-tests were employed to find the significant change among enzymatic activities in initial waste mixture and final vermicompost.

\subsection{Fourier transform infrared (FT-IR) analysis}

The Fourier transform infrared (FT-IR) study was performed on a NicoletTM5700 spectrometer. $2 \mathrm{mg}$ of each samples were assorted with $400 \mathrm{mg} \mathrm{KBr}$ and pressed under vacuum to make potassium bromide $(\mathrm{KBr})$ pellets. Both samples and $\mathrm{KBr}$ were dehydrated discretely at $105^{\circ} \mathrm{C}$ to remove moisture before production of the pellets. The bands measured were ranged from 400 to $4000 \mathrm{~cm}-1$ with interval of $4 \mathrm{~cm}-1$. Baseline corrections were made in spectra and absorbance was normalized for unity of presentation and analysis.

\subsection{Thermogravimetric (TGA) analysis}

Thermogravimetric analysis (TGA) was accomplished using a simultaneous thermal analyzer (PerkinElmer STA 600, USA). The samples were grounded (15-25 mg) and sieved to $0.2 \mathrm{~mm}$ particle size. The analysis was completed on a dry basis by means of aluminum crucibles $(60 \mu \mathrm{L})$ under synthetic air atmosphere (flow rate maintained at $100 \mathrm{ml} \mathrm{min}-1)$. Temperature ranged from $20-800{ }^{\circ} \mathrm{C}$ and heating rate of $10^{\circ} \mathrm{C}$ min-1 was used with pressure sustained at $101 \mathrm{kPa}$. 


\subsection{Differential scanning calorimetry (DSC) analysis}

Differential scanning calorimetry (DSC, Metller Toledo 822E, India) was carried out on finely ground samples. Covered aluminum crucibles were used for weighing samples (8 - $10 \mathrm{mg})$. Thermal analysis was accomplished in reduced nitrogen atmosphere (temperature range: 0 $220 \circ \mathrm{C}$, heating rate $10 \circ \mathrm{C} / \mathrm{min})$.

\subsection{Scanning electron microscopy (SEM) analysis}

Scanning electron microscopy (SEM) of vermicompost samples was conducted through a scanning electron microscope (Nova NanoSEM 450, Czech Republic). The samples prepared with glutaraldehyde were attached on specimen holder. The mounts were dried under a high vacuum and coating was performed. Scrutiny of these specimens was made at 4000X magnifications.

\section{Result and Discussion}

\subsection{Changes in physico-chemical properties}

In this study, the final vermicompost was more stabilized and having nutrient rich profile than initial substrate (Table 2). The physico-chemical properties of final vermicompost were found to differ considerably as equated to initial substrate. The $\mathrm{pH}$ of the substrate decreased significantly (ANOVA; $F=3,098, p<0.001$ ) through progression of vermicomposting process and it was 7.25 in final vermicompost as compared to 8.35 in initial substrate. The decline in $\mathrm{pH}$ may be credited to the production of carbon dioxide $\left(\mathrm{CO}_{2}\right)$, ammonia $\left(\mathrm{NH}_{3}\right)$, nitrates $\left(\mathrm{NO}_{3}-\right.$ ), orthophosphates ( $\mathrm{PO}_{4-3}$ ) and organic acids during bioconversion process (Sharma and Garg, 2017, 2019; Yuvaraj et al., 2018; Karmegam et al., 2019). During the vermicomposting process, carboxylic and phenolic groups of humic acids (HAs) were neutralized by intestinal $\mathrm{Ca}$ and $\mathrm{NH}_{3}$ secreted by earthworms (Sharma and Garg, 2017, 2018). Consequently, the pH of final vermicompost tended toward neutral range. In the present study, lowering of $\mathrm{pH}$ during vermicomposting process assisted to conserve nitrogen in final vermicompost (Sharma and Garg, 2017; Arora and Kaur, 2019). The electrical conductivity (EC) increased significantly (ANOVA; $F=4,725, p<0.001$ ) from 1.27 to $2.79 \mathrm{mS} \mathrm{cm}-1$ in initial substrate and final vermicompost, respectively. The rise in EC was due to degradation of organic matter and elevated levels of soluble mineral salts in available forms during vermicomposting (Lim et al., 2011; Sharma and Garg, 2017, 2018; Karmegam et al., 2019). Total organic carbon (TOC) significantly decreased by $21.70 \%$ in final vermicompost in comparison to initial waste mixture 
(Table 2) (ANOVA; $F=177.76, p<0.001$ ). This trend of TOC loss can be ascribed to the organic matter degradation and mineralization. Also, respiratory activity and assimilation of carbon by microbial population and earthworms led to decrease in organic carbon (Sharma and Garg, 2017, 2018; Karmegam et al., 2019). The low level of TOC in final vermicompost showed humic acid richness indicating stabilization of the final product (Goswami et al., 2016; Sharma and Garg, 2017). Furthermore, increased level of total Kjeldahl nitrogen was noticed in the final vermicompost (16.84 $\mathrm{g} \mathrm{Kg}$-1) i.e. $108.9 \%$ as compared to initial waste mixture $(8.06 \mathrm{~g} \mathrm{Kg}$ 1) (ANOVA; $F=414.71, p<0.001$ ) (Table 2). Rise in TKN value may be ascribed to the mineralization of nitrogenous organic substrate (mainly proteins) and activity of $\mathrm{N}$-fixers and microorganisms (Gómez-Brandón et al., 2013; Sharma and Garg, 2019). Further, excretory substances of earthworms such as body fluids, coelomic fluids (mucus), growth stimulating hormones, enzymes and dead earthworms augmented total nitrogen of final vermicompost (Arumugam et al., 2017; Sharma and Garg, 2017, 2018, 2019). Likewise, a significant increase of $84.89 \%$ was noticed in total phosphorus (TP) of final vermicompost (ANOVA; $F=325.72$, $p<0.001$ ) (Table 2). The increase in TP may be attributed to the mineralization of phosphorus by the activity of gut and faecal phosphatases, which were further complemented by Psolubilizing microbes during vermicomposting (Hanc and Pliva, 2013; Suthar et al., 2015; Sharma and Garg, 2017, 2018, 2019). Potassium (K) was also found to be higher during vermicomposting process and was increased from 13.27 to $16.17 \mathrm{~g} \mathrm{Kg}-1$ in the initial substrate and final vermicompost respectively (ANOVA; $F=52.03, p<0.001$ ). Mineralization of $\mathrm{K}$ mainly occurs in the gut of earthworms through endo or exogenic enzymes (Yadav et al., 2013; Sharma and Garg, 2017, 2018, 2019). The C/N ratio shows the stability and maturity levels of compost/ vermicompost. In the present study $\mathrm{C} / \mathrm{N}$ ratio significantly decreased by $62.53 \%$ (21.66) in final vermicompost as compared to initial substrate (ANOVA; $F=583.90, p<0.001$ ) (Table 2). The degradation and mineralization of organic matter and loss of carbon in respiratory activity and $\mathrm{N}$ enrichment through progression of vermicomposting process led to decreased C/N ratio in final vermicompost (Malafaia et al., 2015; Sharma and Garg, 2017, 2018, 2019). Also, increase in humification rate and decomposition of complex substances such as lignin, cellulose and hemicellulose resulted in reduced $\mathrm{C} / \mathrm{N}$ ratio (Das et al., 2016; Sharma and Garg, 2017). As C/N ratio below 20 is a good indicator of vermicompost maturity (Morais and Queda, 2003), therefore vermicompost produced in the present (21.66) study could be considered as mature and stable. The C/P ratio of final vermicompost decreased by $57.66 \%$ and was found to be 25.27 as compared to 59.69 in initial substrate (ANOVA; $F=781.91$, $p<0.001)$. The loss of carbon and increase in phosphorus content during vermicomposting 
operation led to reduced C/P ratio in vermicomposted material (Sharma and Garg, 2017; Karmegam et al., 2019). Based on the nutrient profile, cow dung spiked organic portion of MSW could be recommended for the production of vermicompost, however it relies on the physico-chemical properties of organic waste. It is well known fact that NPK are essential nutrients that augment plant growth and productivity. Therefore, the nutrient rich profile of MSW vermicompost, proved its appropriateness for agricultural application. Hence, it can be stated that vermicomposting of OPMSW has immense potential for recycling and recovery of plant nutrients from wastes. 
Table 2 Physico-chemical properties of substrate material at different time-intervals during vermicomposting $($ mean $\pm S E, n=3)$

\begin{tabular}{llllllll}
\hline Parameters & 0 days & 14th day & 28th day & 42nd day & 56th day & 70th day & 84th day \\
\hline pH & $8.35 \pm 0.01 \mathrm{a}$ & $8.12 \pm 0.00 \mathrm{~b}$ & $7.96 \pm 0.01 \mathrm{c}$ & $7.63 \pm 0.01 \mathrm{~d}$ & $7.45 \pm 0.01 \mathrm{e}$ & $7.37 \pm 0.00 \mathrm{f}$ & $7.25 \pm 0.01 \mathrm{~g}$ \\
$\mathrm{EC}(\mathrm{mS} \mathrm{cm}-1)$ & $1.27 \pm 0.01 \mathrm{~g}$ & $1.41 \pm 0.01 \mathrm{f}$ & $1.65 \pm 0.01 \mathrm{e}$ & $1.79 \pm 0.01 \mathrm{~d}$ & $2.28 \pm 0.01 \mathrm{c}$ & $2.50 \pm 0.01 \mathrm{~b}$ & $2.79 \pm 0.01 \mathrm{a}$ \\
TOC $(\mathrm{g} \mathrm{Kg}-1)$ & $465.9 \pm 0.99 \mathrm{a}$ & $420.9 \pm 3.90 \mathrm{~b}$ & $411.2 \pm 2.41 \mathrm{~b}$ & $388.0 \pm 2.27 \mathrm{c}$ & $378.6 \pm 1.74 \mathrm{~cd}$ & $375.0 \pm 2.25 \mathrm{~cd}$ & $364.8 \pm 3.62 \mathrm{~d}$ \\
TKN $(\mathrm{g} \mathrm{Kg}-1)$ & $8.06 \pm 0.12 \mathrm{~g}$ & $9.46 \pm 0.20 \mathrm{f}$ & $10.44 \pm 0.17 \mathrm{e}$ & $12.13 \pm 0.17 \mathrm{~d}$ & $13.76 \pm 0.17 \mathrm{c}$ & $15.30 \pm 0.12 \mathrm{~b}$ & $16.84 \pm 0.12 \mathrm{a}$ \\
Total P $(\mathrm{g} \mathrm{Kg}-1)$ & $7.81 \pm 0.12 \mathrm{e}$ & $8.53 \pm 0.04 \mathrm{e}$ & $9.91 \pm 0.12 \mathrm{~d}$ & $10.44 \pm 0.03 \mathrm{~d}$ & $11.41 \pm 0.08 \mathrm{c}$ & $13.24 \pm 0.29 \mathrm{~b}$ & $14.44 \pm 0.06 \mathrm{a}$ \\
Total K $(\mathrm{g} \mathrm{Kg}-1)$ & $13.27 \pm 0.12 \mathrm{c}$ & $13.52 \pm 0.13 \mathrm{c}$ & $13.60 \pm 0.14 \mathrm{c}$ & $13.75 \pm 0.20 \mathrm{bc}$ & $14.09 \pm 0.19 \mathrm{bc}$ & $14.55 \pm 0.05 \mathrm{~b}$ & $16.17 \pm 0.08 \mathrm{a}$ \\
C/N ratio & $57.81 \pm 0.95 \mathrm{a}$ & $44.50 \pm 0.67 \mathrm{~b}$ & $39.39 \pm 0.54 \mathrm{c}$ & $32.01 \pm 0.40 \mathrm{~d}$ & $27.53 \pm 0.34 \mathrm{e}$ & $24.51 \pm 0.15 \mathrm{ef}$ & $21.66 \pm 0.13 \mathrm{f}$ \\
C/P ratio & $59.69 \pm 0.83 \mathrm{a}$ & $49.35 \pm 0.24 \mathrm{~b}$ & $41.51 \pm 0.30 \mathrm{c}$ & $37.18 \pm 0.25 \mathrm{~d}$ & $33.17 \pm 0.19 \mathrm{e}$ & $28.35 \pm 0.56 \mathrm{f}$ & $25.27 \pm 0.27 \mathrm{~g}$ \\
\hline
\end{tabular}

Different alphabetical letters in each parameter during vermicomposting represent statistically significant difference at $p<0.001$ by Duncan's Multiple Range Test (DMRT) 


\subsection{Enzymatic activities}

Several enzyme activities were estimated in pre-composted waste mixture and final vermicompost to determine organic matter decomposition during microbial driven vermicomposting process. The variations in the enzyme activities of urease, dehydrogenase, phosphatase, protease and $\beta$-glucosidase (main enzymes tangled in urea and aerobic oxidative metabolism, and also breakdown of phosphate esters, polypeptides and polysaccharides, in that order) at two-time intervals are depicted in Fig. 1.

The urease activity, which catalyzes hydrolysis of urea $\left(\mathrm{CH}_{4} \mathrm{~N}_{2} \mathrm{O}\right)$, yielding $\mathrm{CO}_{2}$ and $\mathrm{NH}_{4+}$, decreased by $22.46 \%$ in final vermicompost ( $\mathrm{t}$ rest; $t=4.14, p=0.054)$ (Fig. 1), probably due to elevated levels of $\mathrm{NH}_{4+-} \mathrm{N}$ in the substrate during last phase of the experimental period, which might be responsible for its suppressed activity ( Ros et al., 2006; Jurado et al., 2014; Sudkolai and Nourbakhsh, 2017). Also, decreased activity of urease can be ascribed to the reduction of $\mathrm{N}$-substrates, which apparently favor microbial activity (Benitez et al., 1999). Our findings were in accordance to Wu et al., (2017) and Sudkolai and Nourbakhsh (2017), who found similar results for the urease activity. Similarly, the phosphomonoesterases hydrolyzes organic phosphomonoesters to inorganic $\mathrm{P}$ (orthophosphate), which inhibits its activity at higher concentration in the substrate (Aira et al., 2007; Fernández-Gómez et al., 2010, 2013). In the present study, acid phosphatase was found to be negatively correlated with available $\mathrm{P}$ and a decrease of $22.31 \%$ was noticed in final vermicompost ( $\mathrm{t}$ test; $t=6.17, p=0.025$ ) (Fig. 1). This result is in consistence to Benitez et al., (2005), who noticed an initial increase and subsequent decrease in phosphatase activity while vermicomposting of lignocellulosic olive waste by employing Eisenia andrei. The dehydrogenase enzyme plays significant role in biological oxidation of organic compounds and transfers hydrogen from substrates to the acceptor molecules (Page, 1982). Dehydrogenase activity determines overall microbial activity and stabilization of organic substrate during vermicomposting. It was recorded as $2.50 \mathrm{mgTPF}$.g1 dw.h-1 in pre-composted waste mixture, which was decreased by $25.20 \%$ in final vermicompost ( $\mathrm{t}$ test; $t=30.30, p=0.001$ ) (Fig. 1). The decrease of dehydrogenase activity in final vermicompost can be attributed to deprivation and diminution of organic matters, indicating stabilization of the initial waste mixture (Alidadi et al., 2016).

Protease enzyme catalyzes breakdown of proteins to peptides and amino acids (Geisseler and Horwath, 2008; Villar et al., 2016). It's activity results in depolymerization of dissolved organic nitrogen from nitrogenous compounds, which is supposed to be very important in nitrogen cycle, as complex forms are not readily available to the micro-organisms (Schimel 
and Bennet, 2004; Aira et al., 2007). The protease activity depends on substrate availability, therefore, could be useful in analyzing the decomposition rates of organic matter (Aira et al., 2007). In the present study, protease activity decreased by $41.72 \%$ in final vermicompost (33.15 $\mu \mathrm{g}$ tyrosine. g-1dw. $2 \mathrm{~h}-1)$ as compared to pre-composted waste mixture (56.88 $\mu \mathrm{g}$ tyrosine. $\mathrm{g}-1 \mathrm{dw} .2 \mathrm{~h}-1)(\mathrm{t}$ test; $t=21.52, p=0.002)($ Fig. 1). The diminution in protease activity can be ascribed to low availability of substrate material during terminal phase of the experimental period, indicating that final product is more stabilized as compared to initial waste mixture. Similar result was reported by Villar et al. (2016), who confirmed significant reductions in protease activity during progression of vermicomposting experiment with sewage sludge. Likewise, $\beta$-glucosidase is involved in carbon cycle, which catalyzes the breakdown of glucosides to glucose and therefore associated with the turnover of carbon (Sinsabaugh and Moorhead,1994; Alef and Nannipieri, 1995). Its activity can be induced by the substrate therefore depends on substrate availability (Alef and Nannipieri, 1995). During vermicomposting process, $\beta$-glucosidase is synthesized and released presumably due to the breakdown of organic wastes and/or increase in microbial growth and activation of their metabolism (Eivazi and Tabatabai, 1990; Aira et al., 2007). In this study, $\beta$-glucosidase activity declined by $39.56 \%$ in final vermicompost and was found to be $2.75 \mathrm{mg}$ PNP. g-1dw.h-1 as compared to $4.55 \mathrm{mg}$ PNP. g-1dw.h-1 in pre-composted waste mixture ( $\mathrm{t}$ test; $t=34.08, p=0.001$ ) (Fig. 1). The decline in $\beta$-glucosidase activity can be credited to depletion of organic substrate in older layers (Aira et al., 2007). The substantial presence and maintenance of extracellular enzyme activities during end phase of experimental period could be attributed to the development of complexes between extracellular enzymes and humic substances that gets protected from denaturation and degradation processes (Jurado et al., 2014; Villar et al., 2016). 


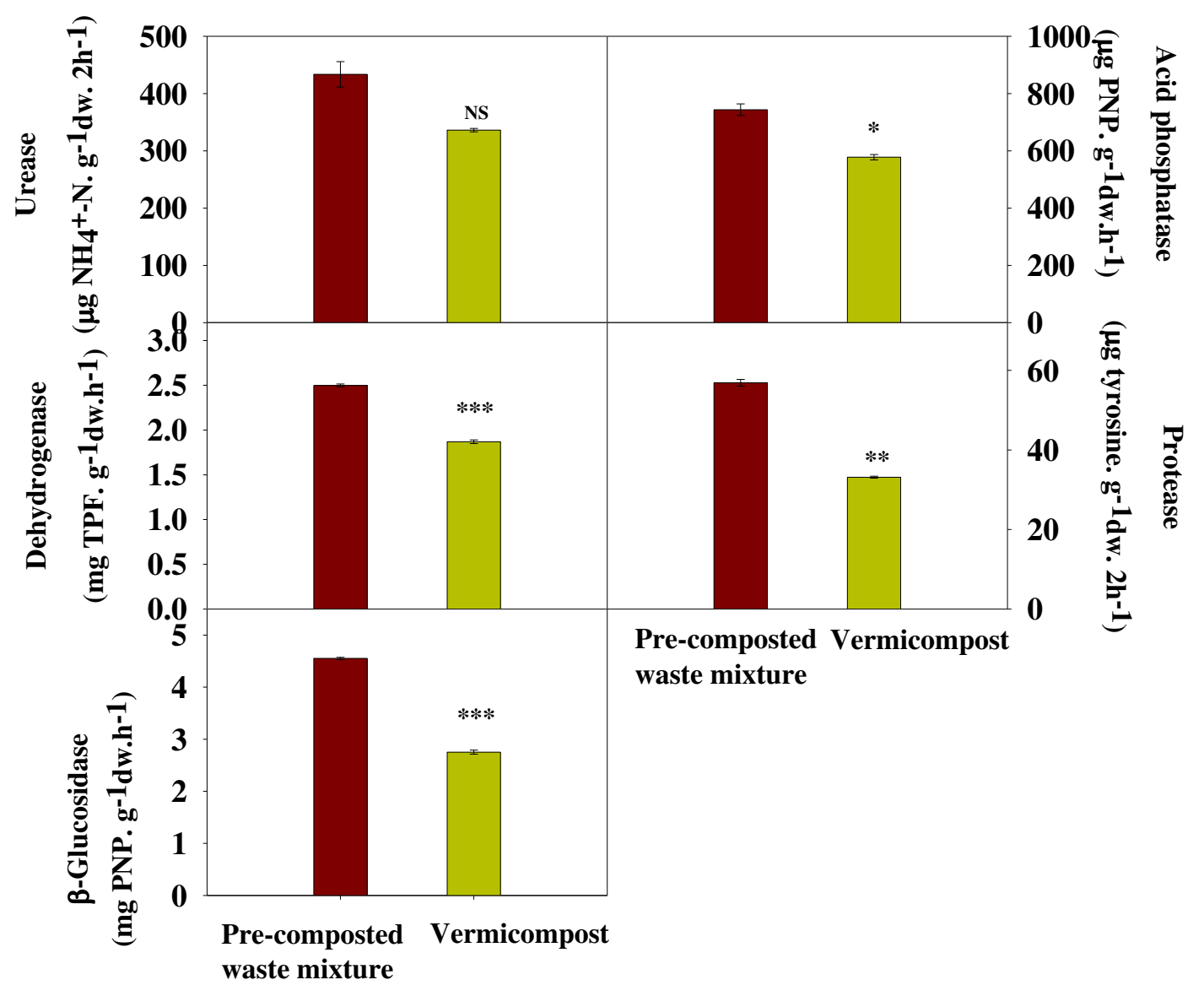

Level of statistically important difference at $\mathrm{p}<0.05(*), \mathrm{p}<0.01(* *), \mathrm{p}<0.001(* * *)$ and NS (non- significant) by Paired Student's t-test

Fig. 1. Changes in enzymatic activities of pre-composted waste mixture and final vermicompost

\subsection{Fourier transform infrared analysis}

The fourier transform infrared (FT-IR) spectroscopy facilitates identification of chemical functional groups of a matter where the absorbance intensity change is used to assess vermicompost stability ( $\mathrm{Lim}$ and $\mathrm{Wu}, 2015$ ). In Fig. 2, the relevant spectral bands of initial waste mixture and final vermicompost are presented. The assignment of infrared (IR) absorptions ascribed to specific functional groups is summarized in Appendix S2.

In comparison to initial waste mixture, the FT-IR spectra of final vermicompost presented significant lessening in the peak intensity at $3387.8 \mathrm{~cm}-1$ reflecting decomposition of phenols and carbohydrates due to reduction in $\mathrm{OH}$ and $\mathrm{CH}_{2}$ structures. $\mathrm{Lim}$ and $\mathrm{Wu}(2015)$, found that 
decreased peak intensity at $3328 \mathrm{~cm}-1$ showed degradation of carbohydrates in palm oil mill effluent (POME) vermicompost. Likewise, Hussain et al. (2015) stated significant reduction in the peak intensity at $3448 \mathrm{~cm}-1$ depicting reduction in phenolic content. Gupta and Garg (2009) reported reduced band height at around 3100-3600 cm-1 in the cow dung vermicompost in comparison to initial substrate. The reduction in peak intensity at 2924.8 and $2834.5 \mathrm{~cm}-1$ in final vermicompost suggested degradation of lipid and carbohydrates due to decrease in aliphatic structures. Droussi et al. (2009), observed decrease of methylene bands (C-H stretch) at 2920 and $2850 \mathrm{~cm}-1$ during progression of composting of olive-mill residues. Comparable outcomes were noticed by Gupta and Garg (2009) and Makni et al. (2010) while maturation study of organic waste compost. No obvious change of intensity was noticed in $\mathrm{C} \equiv \mathrm{N}$ stretching vibrations of nitriles at $2342.3 \mathrm{~cm}-1$. Soobhany et al. (2017), observed $\mathrm{C} \equiv \mathrm{N}$ vibrations of nitriles at $2329 \mathrm{~cm}-1$ in compost and vermicompost of paper waste. A prominent increase in the band intensity at $1644.8 \mathrm{~cm}-1$ was noticed in final vermicompost as compared to initial waste mixture. This change could have been attributed to increase in aromatic groups during vermicomposting. Droussi et al. (2009) found increase in band intensity at 1650-1640 cm-1 due to aromatic $\mathrm{C}=\mathrm{C}$ stretching in compost produced from olive mill residues. Similar result was observed by Makni et al. (2010) whilst studying maturity of organic waste composts. Soobhany et al. (2017) observed prominent shoulder around 1635 and $1630 \mathrm{~cm}-1$ due to N-H bending vibrations correspond to Amide $\mathrm{I}$ species and $\mathrm{C}=\mathrm{C}$ stretching of aromatic compounds in compost and vermicompost samples. No remarkable change was found at peak intensity of $1425.3 \mathrm{~cm}-1$, followed by emergence of a sharp peak at $1377.4 \mathrm{~cm}-1$ due to N-O stretching of nitro group (Smidt et al. 2002; Hussain et al. 2015). Emergence of similar N-O stretching vibration was noticed by Hussain et al., (2015) and Rajiv et al. (2013) at peak intensity of 1384 and $1381 \mathrm{~cm}-1$ respectively in vermicompost samples. The peak intensity increased at 1045.35 cm-1 due to elevated levels of aromatic ethers and polysaccharides. Droussi et al. (2009) observed large peak bandwidth around 1070-1030 $\mathrm{cm}-1$ due to aromatic ethers and carbohydrates in compost. Analogous results were described by Hussain et al. (2015) and Rajiv et al. (2013). An appreciable increase in peak intensities at 777.9, 680.2 and $460.7 \mathrm{~cm}-1$ was observed in final vermicompost (Fig. 2). This result was in accordance to Makni et al. (2010), who noticed prominent increase in peak intensities at 873.4, 778.5 and $467.9 \mathrm{~cm}-1$ due to increase of silicates $(\mathrm{Si}-\mathrm{O}-\mathrm{Si})$, aromatic ethers and polysaccharides $(\mathrm{C}-\mathrm{H}$ stretch) in ready compost samples. The peaks between 777.9 and $460.7 \mathrm{~cm}-1$ with minor variations in final vermicompost can equally be ascribed to alkyl halides and polysulfide groups (Reusch, 2013). This finding was in consistent with Soobhany et al. (2017), who observed small differing peaks 
between 875 and $456 \mathrm{~cm}-1$ due to alkyl halides and polysulfide groups in compost and vermicompost and were more intense in vermicompost samples.

The findings of FT-IR study revealed disappearance of polysaccharides, carbohydrates and aliphatic methylene from the initial waste mixture whilst aromatic compounds, nitro group and humic structures appeared in MSW vermicompost depicting its stability and maturity.

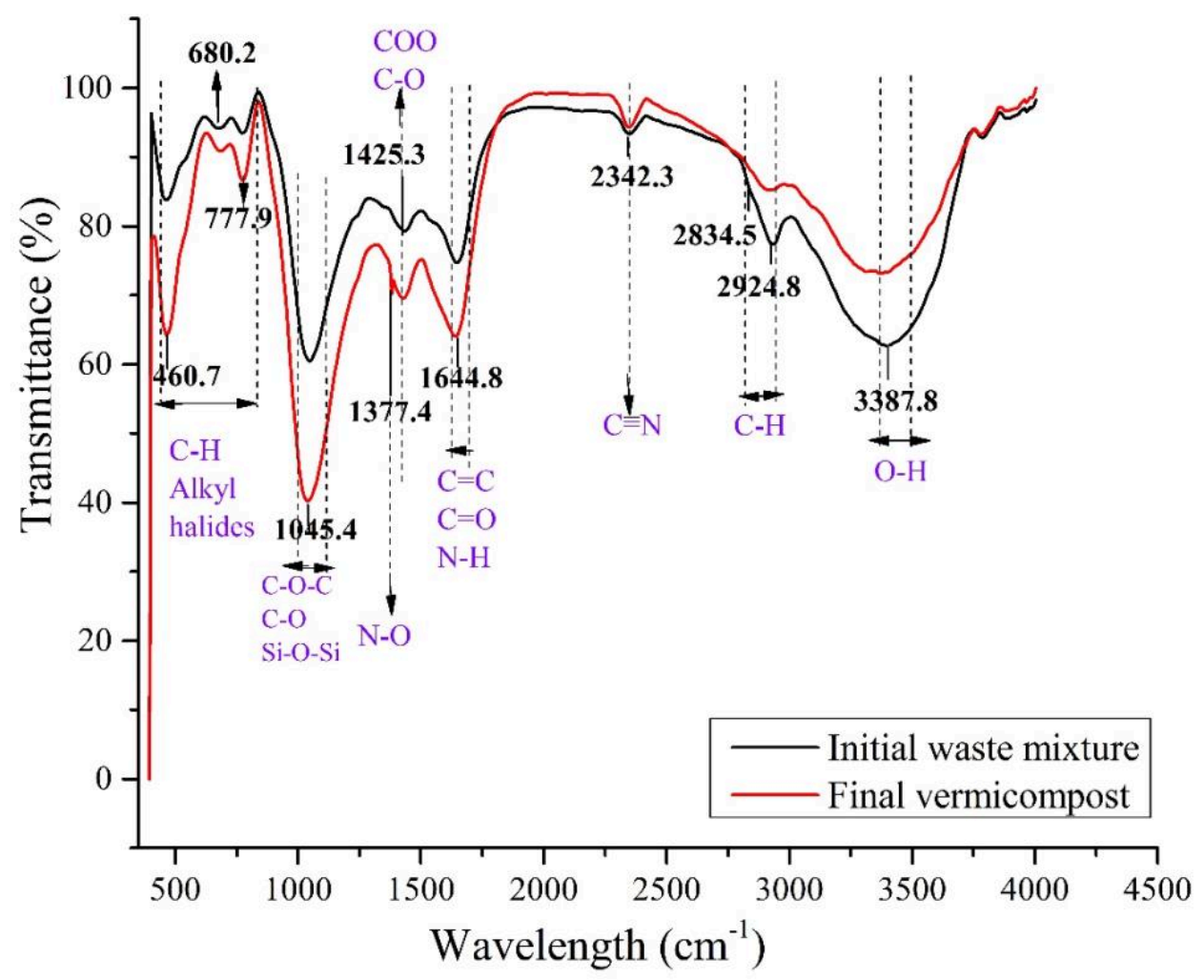

Fig. 2. FT-IR spectra of the pre-composted waste mixture and final vermicompost 


\subsection{Thermogravimetric analysis}

Thermogravimetry (TG) is a thermal technique which is used to examine the changes in mass of a sample at increasing temperature and constant heating rate. TG analysis of substrate material at two-time intervals during vermicomposting revealed thermal stability of samples explained by mass loss due to dehydration, oxidation and degradation (Bhat et al., 2017; Khatua et al., 2018). The derivative thermogravimetric (DTG) curves were found from the first derivative of thermogravimetric profiles. The TG and DTG curves of the initial waste mixture and final vermicompost are presented in Fig. 3 a \& b. Both the samples showed gradual decrease in mass under heating conditions. TG profiles showed higher percentage of mass loss in the initial waste mixture as compared to final vermicompost (Fig. 3a). Under atmospheric conditions, the total mass losses at $800{ }^{\circ} \mathrm{C}$ were 47.5 and $38 \%$ for initial waste and vermicompost, respectively (Fig. 3a). These changes in mass percentage could be ascribed to higher volatile solids in initial waste mixture (Lim et al., 2014). Consequently, vermicompost was comparatively more stabilized as it contained higher amount of heat resistant compounds due to increased molar complexity of carbohydrates and extent of aromaticity (Ravindran et al., 2013; Kahtua et al., 2018). The decrease in mass percentage up to $140{ }^{\circ} \mathrm{C}$ was owed to the dehydration or loss of residual water from the specimens that could have been seen in the first peak of DTG profile in the temperature ranged between $30-140{ }^{\circ} \mathrm{C}$ (DTG1) (Fig. 3b). Kahtua et al., (2018) and Soobhany et al., (2017) observed analogous results in the vermicompost samples of banana stem and MSW respectively. Following dehydration, a progressive decrease in mass percentage was noticed at $\sim 155-350{ }^{\circ} \mathrm{C}$ (DTG2). This peak was ascribed to the decarboxylation reactions of easily degradable materials and thermal decomposition of carbonaceous biomass such as aliphatic compounds, carbohydrates, and carboxylic groups (Ravindran et al., 2013; Soobhany et al., 2017; Kahtua et al., 2018). The decay of cellulose, hemicellulose and microbial cell wall could have also been responsible for the appearance of this peak (Kaloustian et al., 1997; Lim and Wu 2015). The peak intensity of DTG2 declined significantly during the vermicomposting progression. The reduction in peak intensity can be ascribed to biochemical conversion of readily decomposable organic matter into more complex humic like substances (Gómez et al., 2007; Lim and Wu, 2015; Wu et al., 2011). The decrease in intensity was in confirmation with the FT-IR study (Fig. 2). A peak (DTG3) appeared at higher temperature range of $\sim 400-550{ }^{\circ} \mathrm{C}$ was ascribed to the mass loss owing to the thermal dissociation and breakdown of extra stable and complex aromatic structures such as lignin (El Ouaqoudi et al., 2015; Soobhany et al., 2017; Kahtua et al., 2018). Thermal degradation of 
aliphatic substances including long chain hydrocarbons and nitrogenous compounds was also supposed to be liable for mass loss above $\sim 400{ }^{\circ} \mathrm{C}$ (Ravindran et al., 2013). The peak DTG3 decreased and moved slightly towards higher temperature and found at $474{ }^{\circ} \mathrm{C}$ in final vermicompost as equated to $468{ }^{\circ} \mathrm{C}$ in initial waste mixture. The shift in peak towards higher temperature showed growth in molecular complexity and aromaticity in vermicompost depicting maturity and stability of sample (Smidt and Lechner, 2005). Eventually, the peak (DTG4) emerged at the temperature range of $650-750{ }^{\circ} \mathrm{C}$ was credited to thermal decay of carbonates (Wu et al., 2011) (Fig. 3b). Its intensity increased slightly with progression of vermicomposting depicting mineralization of organic matter.

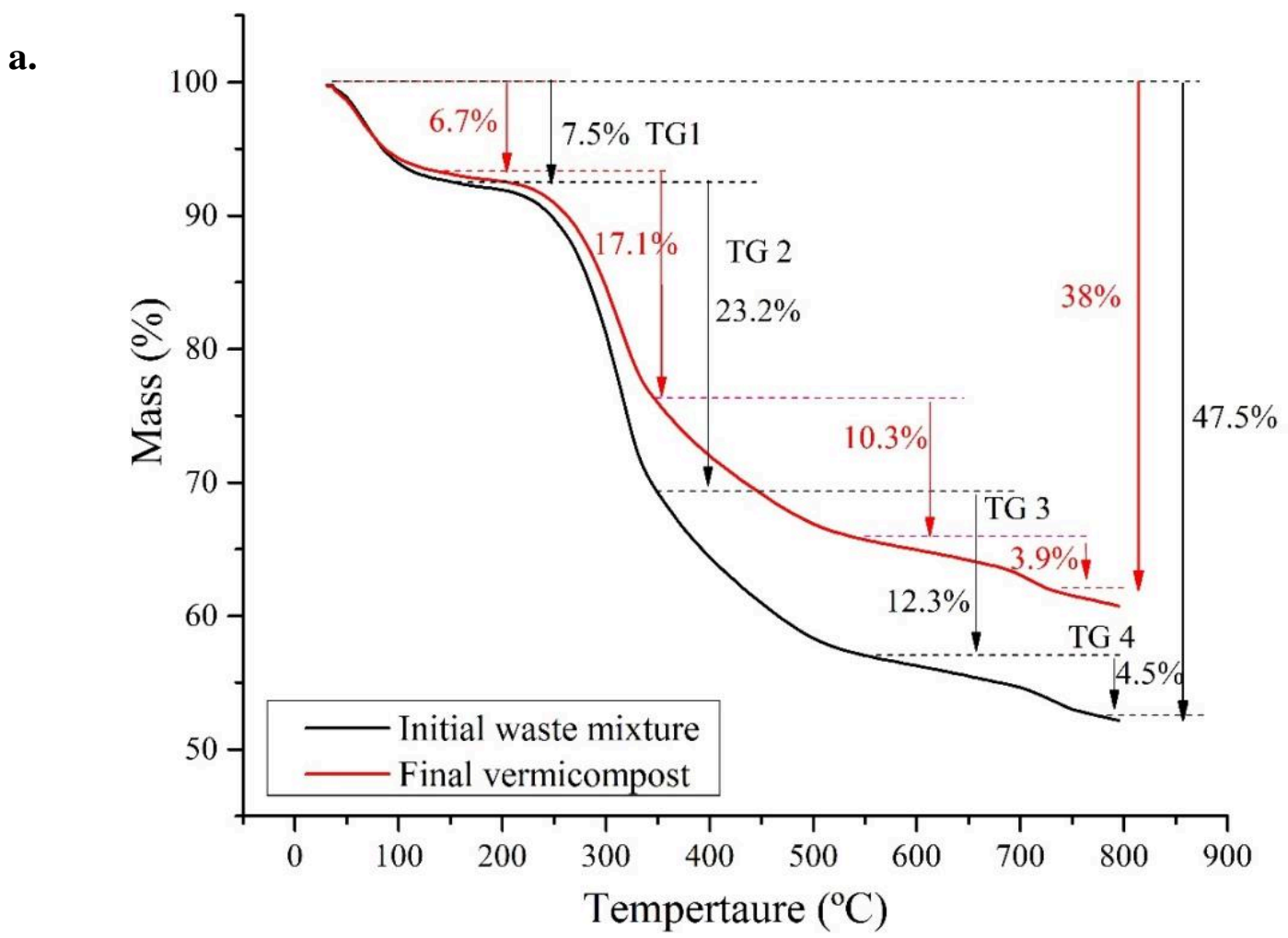


b.

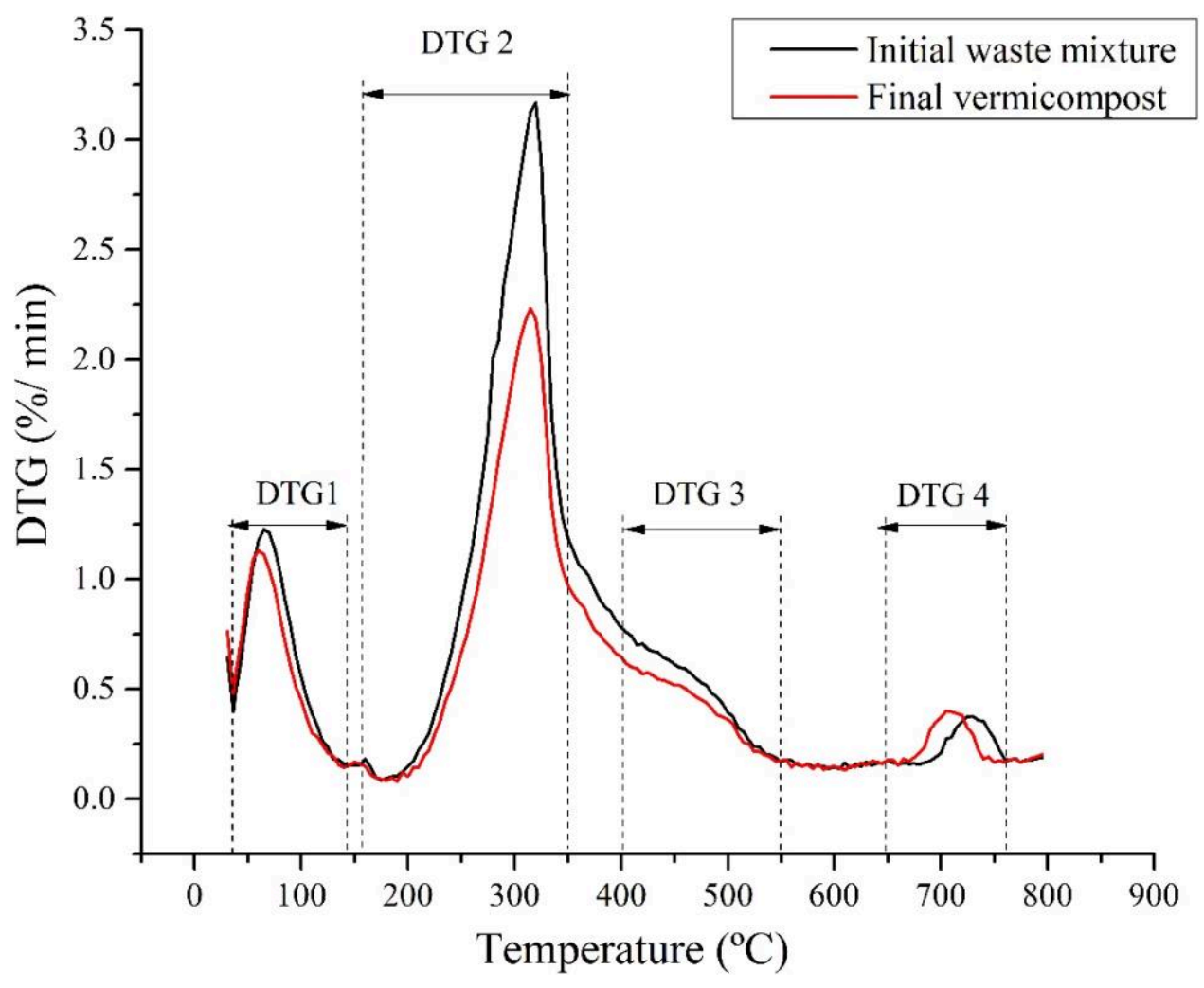

Fig. 3. a. Percentage mass loss and $\boldsymbol{b}$. derivative thermogravimetry (DTG) curves from thermogravimetry exploration of the pre-composted waste mixture and final vermicompost

\subsection{Differential scanning calorimetry}

Differential scanning calorimetry (DSC) is a thermo-analytical procedure which is used to assess the physico-chemical changes during the composting and vermicomposting which exhibit exothermic reactions under heat capacity. The DSC curves of initial and final vermicompost are revealed in Fig. 4. DSC curve of initial feed mixture showed two energy requiring endothermic peaks at $94.4{ }^{\circ} \mathrm{C}$ and $171.1{ }^{\circ} \mathrm{C}$ respectively. These peaks were characterized by loss of residual water and peripheral polysaccharide chains (Critter and Airoldi, 2006; Soobhany et al., 2017). Analogous results were conveyed by Soobhany et al. (2017), who observed two endothermic peaks at 83.8 and $166.4^{\circ} \mathrm{C}$. In the present study, a sharp low temperature endothermic peak was detected at $84.6{ }^{\circ} \mathrm{C}$, shows higher maturity of vermicompost sample as compared to initial waste mixture (Provenzano et al., 2000; Soobhany et al., 2017) (Fig. 4). Likewise, second peak at $161.2{ }^{\circ} \mathrm{C}$ was in accordance to DTG2 (Fig. 3b) that can be attributed to the energy needed for bond breakage during degeneration of aliphatic 
and carbohydrate compounds. Furthermore, molecular repositioning and orientation due to degradation of aliphatic, carbohydrates, peptides and other aromatic compounds might have also been responsible for the appearance of second peak (Fernández et al., 2012; Soobhany et al., 2017). The second endothermic peak at $161.2{ }^{\circ} \mathrm{C}$ appeared slightly flattened in final vermicompost due to reduced degradation of complex compounds (present in lesser amount) depicting stabilization and maturity of final vermicompost. This result was in accordance to Soobhany et al. (2017), who found virtually flattened endothermic peak at $\sim 165^{\circ} \mathrm{C}$ in vermicompost sample as compared to compost. The DSC curves showed that vermicompost was more stabilized product as compared to the initial waste mixture depicted by reduced intensity of endothermic peaks up to $220^{\circ} \mathrm{C}$ suggesting low availability of complex compounds in vermicompost sample.

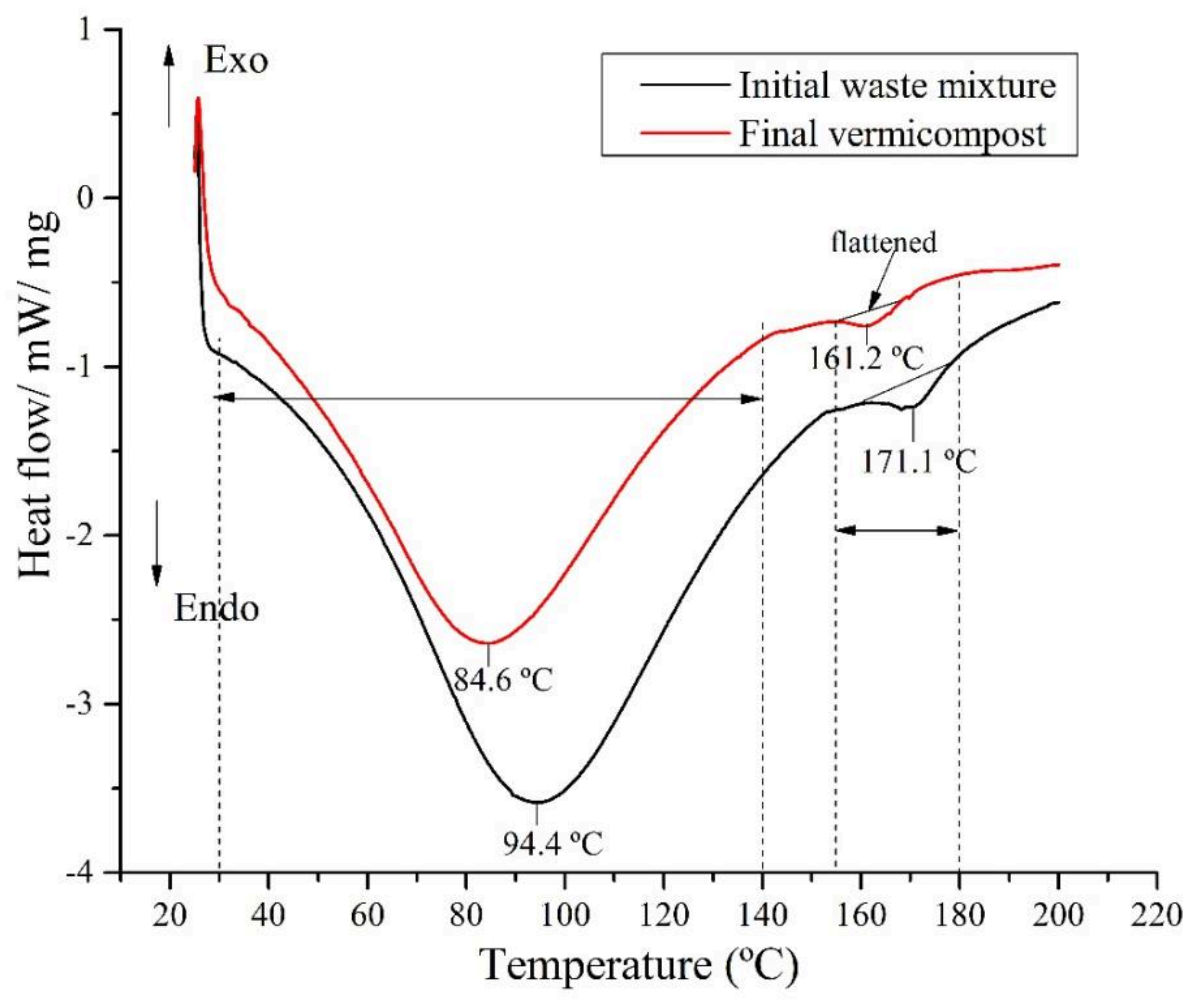

Fig. 4. Differential calorimetry curve of the initial feed mixture and final vermicompost 


\subsection{Scanning electron microscopy (SEM)}

Snapshots obtained from SEM of initial waste mixture and final vermicompost are compared in Fig. 5. The study discovered that initial waste mixture was relatively compacted and flock like structure, whereas the vermicompost had more porous, fragmented and granular structure (Fig. 5a \& b). During vermicomposting, the earthworms (Eisenia fetida) ingested and pulverized the initial waste mixture in the gizzard (Ali et al., 2015). Further disintegration of substrate material was assisted by different enzymes and enteric microbial activities mainly by hydrolytic bacteria present in the earthworm's gut (Arancon et al., 2005; Bhat et al., 2017). Our results are in consistence with Unuofin and Mnkeni (2014), who observed fine granular structure of vermicomposts produced from cow dung and paper waste mixtures. Similar results were reported by various researchers who performed SEM exploration to elucidate changes in surface morphology of initial substrate and final vermicomposted mixtures (Kumar et al., 2014; Rajpal et al., 2014; Bhat et al., 2015; Hussain et al., 2016).

a.

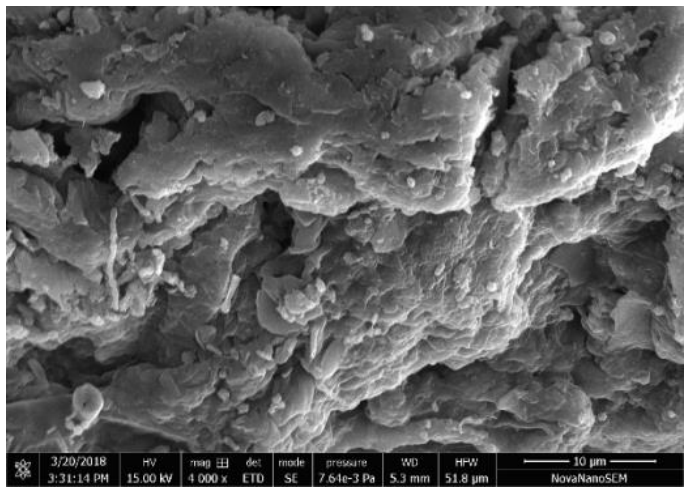

b.

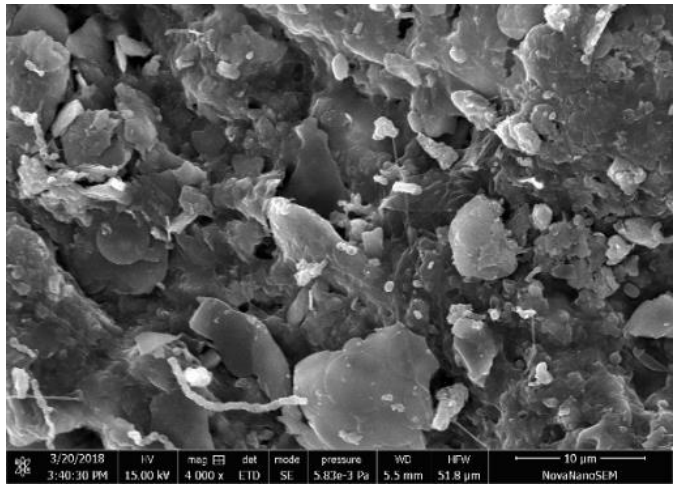

Fig. 5. Scanning electron microscopy (4000x) of a. pre-composted waste mixture and; b. final vermicompost

\section{Conclusion}

The OPMSW mixed with CD could be utilized in vermicomposting employing earthworm spp. Eisenia fetida. The enrichment of TKN, TP and TK contents, and decrease in TOC, C/N and $\mathrm{C} / \mathrm{P}$ ratios depicted maturity and stability of the final product. Likewise, decline of urease, phosphatase, protease and $\beta$-glucosidase activities suggested decomposition of $\mathrm{N}$-substrates, phosphate esters, polypeptides and polysaccharides, respectively in final vermicompost. The spectroscopic and thermal analyses further supported stability and maturity of the end product reflected by reductions in readily degradable polysaccharides and aliphatic compounds and increase in aromatic groups. Also, SEM micrographs revealed relatively larger surface areas 
and much flakier structure of final vermicompost. In conclusion, these findings will contribute to better understanding of vermicompost stability and maturation study using different conventional and advanced instrumentation. The spectroscopic, thermal and structural analyses could easily be used to establish maturity and stability in compost science, which are comparatively less time consuming and more accurate over conventional analyses. The vermistabilzation of OPMSW could also help to develop an eco-friendly and alternative approach for nutrient recovery and waste management for a green and healthy environment.

\section{Acknowledgements}

Authors are grateful to Director and Dean, Institute of Environment and Sustainable Development, Banaras Hindu University. Authors express their sincere thanks to Head, Department of Environment and Sustainable Development, IESD, BHU for facilitating with necessary infrastructure. RPS is thankful to Science and Engineering Research Board, Department of Science and Technology for providing monetary support in form of project and VS gratefully acknowledged to Indian Council of Medical Research for providing JRF and SRF.

Conflict of Interest On behalf of all authors, the corresponding author states that there is no conflict of interest.

\section{References}

Aira, M., Monroy, F., Domínguez, J., 2007. Earthworms strongly modify microbial biomass and activity triggering enzymatic activities during vermicomposting independently of the application rates of pig slurry. Sci. Total Environ. 385, 252-261. https://doi.org/10.1016/j.scitotenv.2007.06.031

Alef, K., Nannipieri, P., Trazar-Cepeda, C., 1995. Phosphatase activity, in: Alef, K., Nannipieri, P. (Eds.), Methods in applied soil microbiology and biochemistry. Academic Press., London, pp. 335-344.

Ali, U., Sajid, N., Khalid, A., Riaz, L., Rabbani, M. M., Syed, J. H., Malik, R. N., 2015. A review on vermicomposting of organic wastes. Environ. Prog. Sustain. Energy. 34, 1050-1062. https://doi.org/10.1002/ep.12100

Alidadi, H., Hosseinzadeh, A., Najafpoor, A. A., Esmaili, H., Zanganeh, J., Takabi, M. D., Piranloo, F. G., 2016. Waste recycling by vermicomposting: Maturity and quality assessment via dehydrogenase enzyme activity, lignin, water soluble carbon, nitrogen, phosphorous and $\begin{array}{llll}\text { other indicators. J. } & \text { Environ. 134-140. }\end{array}$ https://doi.org/10.1016/j.jenvman.2016.07.025 
Allen, S.E., Grimshaw, H.M., Parkinson, J.A., Quarmby, C., 1974. Chemical analysis of ecological materials. Blackwell Scientific, Oxford.

Amir, S., Jouraiphy, A., Meddich, A., El Gharous, M., Winterton, P., Hafidi, M., 2010. Structural study of humic acids during composting of activated sludge-green waste: elemental analysis, FTIR and 13C NMR. J. Hazard. Mater. 177, 524-529. https://doi.org/10.1016/j.jhazmat.2009.12.064

Arancon, N. Q., Edwards, C. A., Bierman, P., Metzger, J. D., Lucht, C., 2005. Effects of vermicomposts produced from cattle manure, food waste and paper waste on the growth and yield of peppers in the field. Pedobiologia. 49, 297-306. https://doi.org/10.1016/j.pedobi.2005.02.001

Arora, M., Kaur, A., 2019. Azolla pinnata, Aspergillus terreus and Eisenia fetida for enhancing agronomic value of paddy straw. Sci. Rep. 9, 1341. https://doi.org/10.1038/s41598-018$37880-1$

Arumugam, K., Renganathan, S., Babalola, O. O., Muthunarayanan, V., 2018. Investigation on paper cup waste degradation by bacterial consortium and Eudrillus eugeinea through vermicomposting. Waste Manage. 74,

185-193.

https://doi.org/10.1016/j.wasman.2017.11.009

Benitez, E., Nogales, R., Elvira, C., Masciandaro, G., Ceccanti, B., 1999. Enzyme activities as indicators of the stabilization of sewage sludges composting with Eisenia foetida. Bioresour. Technol. 67, 297-303. https://doi.org/10.1016/S0960-8524(98)00117-5

Benitez, E., Sainz, H., Nogales, R., 2005. Hydrolytic enzyme activities of extracted humic substances during the vermicomposting of a lignocellulosic olive waste. Bioresour. Technol. 96, 785-790. https://doi.org/10.1016/j.biortech.2004.08.010

Bhat, S. A., Singh, J., Vig, A. P., 2015. Potential utilization of bagasse as feed material for earthworm Eisenia fetida and production of vermicompost. Springerplus. 4, 11. https://doi.org/10.1186/s40064-014-0780-y

Bhat, S. A., Singh, J., Vig, A. P., 2016. Effect on growth of earthworm and chemical parameters during vermicomposting of pressmud sludge mixed with cattle dung mixture. Procedia Environ. Sci. 35, 425-434. https://doi.org/10.1016/j.proenv.2016.07.025

Bhat, S. A., Singh, J., Vig, A. P., 2017. Instrumental characterization of organic wastes for evaluation of vermicompost maturity. Journal of Analytical Science and Technology. 8, 1-12. https://doi.org/10.1186/s40543-017-0112-2

Casida Jr, L. E., Klein, D. A., Santoro, T., 1964. Soil dehydrogenase activity. Soil science. 98, 371-376.

Chapman, S. J., Campbell, C. D., Fraser, A. R., Puri, G., 2001. FTIR spectroscopy of peat in and bordering Scots pine woodland: relationship with chemical and biological properties. Soil Biol. Biochem. 33, 1193-1200. https://doi.org/10.1016/S0038-0717(01)00023-2 
Critter, S. A., Airoldi, C., 2006. Thermal analysis of Brazilian tropical soils originating from different sources. J. Braz. Chem. Soc. 17, 1250-1258. http://dx.doi.org/10.1590/S010350532006000700009

Das, D., Bhattacharyya, P., Ghosh, B. C., Banik, P., 2016. Bioconversion and biodynamics of Eisenia foetida in different organic wastes through microbially enriched vermiconversion technologies. Ecol. Eng. 86, 154-161. https://doi.org/10.1016/j.ecoleng.2015.11.012

Droussi, Z., D’orazio, V., Provenzano, M. R., Hafidi, M., Ouatmane, A., 2009. Study of the biodegradation and transformation of olive-mill residues during composting using FTIR spectroscopy and differential scanning calorimetry. J. Hazard. Mater. 164, 1281-1285. https://doi.org/10.1016/j.jhazmat.2008.09.081

Eivazi, F., Tabatabai, M. A., 1988. Glucosidases and galactosidases in soils. Soil Biol. Biochem. 20, 601-606. https://doi.org/10.1016/0038-0717(88)90141-1

Eivazi, F., Tabatabai, M. A., 1990. Factors affecting glucosidase and galactosidase activities in soils. Soil Biol. Biochem. 22, 891-897. https://doi.org/10.1016/0038-0717(90)90126-K

Eivazi, F., Tabatabai, M.A. 1972. Phosphatases in soils. Soil Biol. Biochem. 9, 167-172. https://doi.org/10.1016/0038-0717(77)90070-0

El Ouaqoudi, F. Z., El Fels, L., Lemée, L., Amblès, A., Hafidi, M., 2015. Evaluation of lignocelullose compost stability and maturity using spectroscopic (FTIR) and thermal (TGA/TDA) analysis. Ecol. Eng. 75, 217-222. https://doi.org/10.1016/j.ecoleng.2014.12.004

Ernesto, V., Ribeiro, C., Hojo, O., Fertonani, F., \& Crespi, M., 2009. Thermal characterization of lignocellulosic residue from different sugarcanes. J. Therm. Anal. Calorim. 97, 653-656. https://doi.org/10.1007/s10973-009-0370- ....

Fernández, J. M., Plaza, C., Polo, A., Plante, A. F., 2012. Use of thermal analysis techniques (TG-DSC) for the characterization of diverse organic municipal waste streams to predict biological stability prior to land application. Waste Manage. 32, 158-164. https://doi.org/10.1016/j.wasman.2011.08.011

Fernández-Gómez, M. J., Díaz-Raviña, M., Romero, E., Nogales, R., 2013. Recycling of environmentally problematic plant wastes generated from greenhouse tomato crops through vermicomposting. Int. J. Environ. Sci. Technol. 10, 697-708. https://doi.org/10.1007/s13762013-0239-7

Fernández-Gómez, M. J., Nogales, R., Insam, H., Romero, E., Goberna, M., 2010. Continuousfeeding vermicomposting as a recycling management method to revalue tomato-fruit wastes from greenhouse crops. Waste $\quad$ Manage. 30, 2461-2468. https://doi.org/10.1016/j.wasman.2010.07.005

Geisseler, D., Horwath, W. R., 2008. Regulation of extracellular protease activity in soil in response to different sources and concentrations of nitrogen and carbon. Soil Biol. Biochem. 40, 3040-3048. https://doi.org/10.1016/j.soilbio.2008.09.001 
Goel, G., Kalamdhad, A.S. 2017. Degraded municipal solid waste as partial substitute for manufacturing fired bricks. Constr. Build. Mater. 155, 259-266. https://doi.org/10.1016/j.conbuildmat.2017.08.067

Gómez, X., Cuetos, M. J., García, A. I., Morán, A., 2007. An evaluation of stability by thermogravimetric analysis of digestate obtained from different biowastes. J. Hazard. Mater. 149, 97-105. https://doi.org/10.1016/j.jhazmat.2007.03.049

Gómez-Brandón, M., Lores, M., Domínguez, J., 2013. Changes in chemical and microbiological properties of rabbit manure in a continuous-feeding vermicomposting system. Bioresour. Technol. 128, 310-316. https://doi.org/10.1016/j.biortech.2012.10.112

Goswami, L., Pratihar, S., Dasgupta, S., Bhattacharyya, P., Mudoi, P., Bora, J., Bhattacharyya, S.S., Kim, K. H., 2016. Exploring metal detoxification and accumulation potential during vermicomposting of Tea factory coal ash: sequential extraction and fluorescence probe analysis. Sci. Rep. 6, 30402. https://doi.org/10.1038/srep30402

Gupta, R., Garg, V. K., 2009. Vermiremediation and nutrient recovery of non-recyclable paper waste employing Eisenia fetida. J. Hazard. Mater. 162, 430-439. https://doi.org/10.1016/j.jhazmat.2008.05.055

Hanc, A., Pliva, P., 2013. Vermicomposting technology as a tool for nutrient recovery from kitchen bio-waste. J. Mater. Cycles Waste Manag. 15, 431-439. https://doi.org/10.1007/s10163-013-0127-8

Hussain, N., Abbasi, T., Abbasi, S. A., 2015. Vermicomposting eliminates the toxicity of Lantana (Lantana camara) and turns it into a plant friendly organic fertilizer. J. Hazard. Mater. 298, 46-57. https://doi.org/10.1016/j.jhazmat.2015.04.073

Hussain, N., Abbasi, T., Abbasi, S. A., 2016. Vermiremediation of an invasive and pernicious weed salvinia (Salvinia molesta). Ecol. Eng. 91, 432-440. https://doi.org/10.1016/j.ecoleng.2016.03.010

Jackson, M. L., 1975. Soil chemical analysis. Prentice-Hall of India, New Delhi.

Jurado, M. M., Suárez-Estrella, F., Vargas-García, M. C., López, M. J., López-González, J. A., Moreno, J., 2014. Evolution of enzymatic activities and carbon fractions throughout composting of plant waste. J. Environ. Manage. 133, 355-364. https://doi.org/10.1016/j.jenvman.2013.12.020

Kaloustian, J., Pauli, A. M., \& Pastor, J., 1997. Etude comparative par analyses thermique et chimique de quelques vegetaux mediterraneens. J. Therm. Anal. 50, 795-805. https://doi.org/10.1007/BF01979209

Kandeler, E., \& Gerber, H. (1988). Short-term assay of soil urease activity using colorimetric determination of ammonium. Biol. Fert. Soils. 6, 68-72. https://doi.org/10.1007/BF00257924

Karmegam, N., Vijayan, P., Prakash, M., Paul, J. A. J., 2019. Vermicomposting of paper industry sludge with cowdung and green manure plants using Eisenia fetida: A viable option 
for cleaner and enriched vermicompost production. J. Clean. Prod. 228, 718-728. https://doi.org/10.1016/j.jclepro.2019.04.313

Khan, D., Kumar, A., \& Samadder, S. R., 2016. Impact of socioeconomic status on municipal solid waste generation rate. Waste Manage. 49, 15-25. https://doi.org/10.1016/j.wasman.2016.01.019

Khatua, C., Sengupta, S., Balla, V. K., Kundu, B., Chakraborti, A., Tripathi, S., 2018. Dynamics of organic matter decomposition during vermicomposting of banana stem waste using Eisenia fetida. Waste Manage. 79, 287-295. https://doi.org/10.1016/j.wasman.2018.07.043

Kumar, D. S., Kumar, P. S., Rajendran, N. M., Anbuganapathi, G., 2013. Compost maturity assessment using physicochemical, solid-state spectroscopy, and plant bioassay analysis. J Agric. Food. Chem. 61, 11326-11331. https://doi.org/10.1021/jf4034943

Kaza, S., Yao, L., Bhada-Tata, P., \& Van Woerden, F., 2018. What a waste 2.0: a global snapshot of solid waste management to 2050. World Bank Publications.

Lim, P. N., Wu, T. Y., Shyang Sim, E. Y., Lim, S. L., 2011. The potential reuse of soybean husk as feedstock of Eudrilus eugeniae in vermicomposting. J. Sci. Food Agric. 91, 26372642. https://doi.org/10.1002/jsfa.4504

Ladd, J. N., Butler, J. H. A., 1972. Short-term assays of soil proteolytic enzyme activities using proteins and dipeptide derivatives as substrates. Soil. Biol. Biochem. 4, 19-30. https://doi.org/10.1016/0038-0717(72)90038-7

Lakhdar, A., Slatni, T., Iannelli, M. A., Debez, A., Pietrini, F., Jedidi, N., Massacci, A., Abdelly, C., 2012. Risk of municipal solid waste compost and sewage sludge use on photosynthetic performance in common crop (Triticum durum). Acta Physiol. Plant. 34, 10171026. https://doi.org/10.1007/s11738-011-0898-2

Lim, S. L., Wu, T. Y., 2015. Determination of maturity in the vermicompost produced from palm oil mill effluent using spectroscopy, structural characterization and thermogravimetric analysis. Ecol. Eng. 84, 515-519. https://doi.org/10.1016/j.ecoleng.2015.09.050

Lim, S. L., Wu, T. Y., 2016. Characterization of matured vermicompost derived from valorization of palm oil mill byproduct. J. Agric. Food Chem. 64, 1761-1769. https://doi.org/10.1021/acs.jafc.6b00531

Lim, S. L., Wu, T. Y., Clarke, C., 2014. Treatment and biotransformation of highly polluted agro-industrial wastewater from a palm oil mill into vermicompost using earthworms. J. Agric. Food Chem. 62, 691-698. https://doi.org/10.1021/jf404265f

Lim, S. L., Lee, L. H., Wu, T. Y. 2016. Sustainability of using composting and vermicomposting technologies for organic solid waste biotransformation: recent overview, greenhouse gases emissions and economic analysis. J. Clean. Prod. 111, 262-278. https://doi.org/10.1016/j.jclepro.2015.08.083 
Malafaia, G., da Costa Estrela, D., Guimarães, A. T. B., de Araújo, F. G., Leandro, W. M., de Lima Rodrigues, A. S., 2015. Vermicomposting of different types of tanning sludge (liming and primary) mixed with cattle dung. Ecol. Eng. 85, 301-306. https://doi.org/10.1016/j.ecoleng.2015.10.010

Makni, H., Ayed, L., Ben Khedher, M., Bakhrouf, A., 2010. Evaluation of the maturity of organic waste composts. Waste Manag. Res. 28, 489-495. https://doi.org/10.1177/0734242X09350786

Morais, F. M. C., Queda, C. A. C., 2003. Study of storage influence on evolution of stability and maturity properties of MSW composts, in; Proceedings of the fourth International Conference of ORBIT association on Biological Processing of Organics: Advances for a sustainable Society Part II, Perth, Australia.

Ndegwa, P. M., Thompson, S. A., Das, K. C., 2000. Effects of stocking density and feeding rate on vermicomposting of biosolids. Bioresour. Technol.71, 5-12. https://doi.org/10.1016/S0960-8524(99)00055-3

Nelson, D.W., Sommers, L.E., 1982. Total carbon and organic carbon and organic matter, in: Page, A.L., Miller, R.H., Keeney, D.R. (Eds.), Method of soil analysis. American Society of Agronomy., Madison, pp. 539-579.

Ostos, J. C., López-Garrido, R., Murillo, J. M., López, R., 2008. Substitution of peat for municipal solid waste-and sewage sludge-based composts in nursery growing media: Effects on growth and nutrition of the native shrub Pistacia lentiscus L. Bioresour Technol. 99, 17931800. https://doi.org/10.1016/j.biortech.2007.03.033

Page, A.L., 1982. Methods of Soil Analysis. Part 2. Chemical and Microbiological Properties. American Society of Agronomy, Soil Science Society of America.

Provenzano, M., Ouatmane, A., Hafidi, M., Senesi, N., 2000. Differential scanning calorimetric analysis of composted materials from different sources. J. Therm. Anal. Calorim. 61, 607-614. https://doi.org/10.1023/A:1010146207459

Rajiv, P., Rajeshwari, S., Venckatesh, R., 2013. Fourier transform-infrared spectroscopy and gas chromatography-mass spectroscopy: reliable techniques for analysis of Parthenium mediated vermicompost. Spectrochim. Acta 6. 116, 642-645. https://doi.org/10.1016/j.saa.2013.08.012

Rajpal, A., Arora, S., Bhatia, A., Kumar, T., Bhargava, R., Chopra, A. K., Kazmi, A. A., 2014. Co-treatment of organic fraction of municipal solid waste (OFMSW) and sewage by vermireactor. Ecol. Eng. 73, 154-161. https://doi.org/10.1016/j.ecoleng.2014.09.012

Ravindran, B., Sravani, R., Mandal, A. B., Contreras-Ramos, S. M., Sekaran, G. 2013. Instrumental evidence for biodegradation of tannery waste during vermicomposting process using Eudrilus eugeniae. J. Therm. Anal. Calorim. 111, 1675-1684. https://doi.org/10.1007/s10973-011-2081-9

Reusch, W., 2013. Infrared spectroscopy [online]. Available from: http://www2.chemistry.msu.edu/faculty/reusch/VirtTxtJml/Spectrpy/Infrared/infrared.htm 
[Accessed 12 September 2016].

Ros, M., Garcia, C., Hernández, T., 2006. A full-scale study of treatment of pig slurry by composting: kinetic changes in chemical and microbial properties. Waste Manag. 26, 11081118. https://doi.org/10.1016/j.wasman.2005.08.008

Schimel, J. P., Bennett, J., 2004. Nitrogen mineralization: challenges of a changing paradigm. Ecology. 85, 591-602. https://doi.org/10.1890/03-8002

Senthil Kumar, D., Satheesh Kumar, P., Rajendran, N. M., Uthaya Kumar, V., Anbuganapathi, G., 2014. Evaluation of vermicompost maturity using scanning electron microscopy and paper chromatography analysis. J. Agric. Food Chem. 62, 2738-2741. https://doi.org/10.1021/jf4054403

Sharma, B., Vaish, B., Srivastava, V., Singh, S., Singh, P., Singh, R. P., 2018. An insight to atmospheric pollution-improper waste management and climate change nexus, in: Oves. M., Khan, M. Z., Ismail, I.M.I (Eds.), Modern Age Environmental Problems and their Remediation. Springer Cham., Singapore, pp. 23-47. https://doi.org/10.1007/978-3-31964501-8_2

Sharma, K., Garg, V. K., 2017. Management of food and vegetable processing waste spiked with buffalo waste using earthworms (Eisenia fetida). Environ. Sci. Pollut. Res. 24, 78297836. https://doi.org/10.1007/s11356-017-8438-2

Sharma, K., Garg, V. K., 2018. Comparative analysis of vermicompost quality produced from rice straw and paper waste employing earthworm Eisenia fetida (Sav.). Bioresour. Technol. 250, 708-715. https://doi.org/10.1016/j.biortech.2017.11.101

Sharma, K., Garg, V. K., 2019. Recycling of lignocellulosic waste as vermicompost using earthworm Eisenia fetida. Environ. Sci. Pollut. Res. 1-12. https://doi.org/10.1007/s11356-01904639-8

Sinsabaugh, R. L., Moorhead, D. L., 1994. Resource allocation to extracellular enzyme production: a model for nitrogen and phosphorus control of litter decomposition. Soil Biol. Biochem. 26, 1305-1311. https://doi.org/10.1016/0038-0717(94)90211-9

Smidt, E., Lechner, P., Schwanninger, M., Haberhauer, G., Gerzabek, M. H., 2002. Characterization of waste organic matter by FT-IR spectroscopy: application in waste science. Appl. Spectrosc. 56, 1170-1175.

Soobhany, N., Gunasee, S., Rago, Y. P., Joyram, H., Raghoo, P., Mohee, R., Garg, V. K., 2017. Spectroscopic, thermogravimetric and structural characterization analyses for comparing Municipal Solid Waste composts and vermicomposts stability and maturity. Bioresour. Technol. 236, 11-19. https://doi.org/10.1016/j.biortech.2017.03.161

Srivastava, V., De Araujo, A. S. F., Vaish, B., Bartelt-Hunt, S., Singh, P., Singh, R. P. 2016. Biological response of using municipal solid waste compost in agriculture as fertilizer supplement. Rev. Environ. Sci. Bio.15, 677-696. https://doi.org/10.1007/s11157-016-9407-9 
Srivastava, V., Gupta, S. K., Singh, P., Sharma, B., Singh, R. P., 2018. Biochemical, physiological, and yield responses of lady's finger (Abelmoschus esculentus L.) grown on varying ratios of municipal solid waste vermicompost. Int. J. Recycl. Org. Waste Agric. 1-10. https://doi.org/10.1007/s40093-018-0210-1

Srivastava, V., Ismail, S. A., Singh, P., Singh, R. P., 2015. Urban solid waste management in the developing world with emphasis on India: challenges and opportunities. Rev. Environ. Sci. Bio.14, 317-337. https://doi.org/10.1007/s11157-014-9352-4

Sudkolai, S. T., Nourbakhsh, F., 2017. Urease activity as an index for assessing the maturity of cow manure and wheat residue vermicomposts. Waste Manage. 64, 63-66. https://doi.org/10.1016/j.wasman.2017.03.011

Suthar, S., Kumar, K., Mutiyar, P. K., 2015. Nutrient recovery from compostable fractions of municipal solid wastes using vermitechnology. J. Mater. Cycles Waste Manag. 17, 174-184. https://doi.org/10.1007/s10163-014-0238-X

Unuofin, F. O., Mnkeni, P. N. S., 2014. Optimization of Eisenia fetida stocking density for the bioconversion of rock phosphate enriched cow dung-waste paper mixtures. Waste Manage. 34, 2000-2006. https://doi.org/10.1016/j.wasman.2014.05.018

Villar, I., Alves, D., Pérez-Díaz, D., Mato, S., 2016. Changes in microbial dynamics during vermicomposting of fresh and composted sewage sludge. Waste Manage. 48, 409-417. https://doi.org/10.1016/j.wasman.2015.10.011

Wang, P., Changa, C. M., Watson, M. E., Dick, W. A., Chen, Y., \& Hoitink, H. A. J., 2004. Maturity indices for composted dairy and pig manures. Soil Biol Biochem. 36, 767-776. https://doi.org/10.1016/j.soilbio.2003.12.012

Weber, J., Kocowicz, A., Bekier, J., Jamroz, E., Tyszka, R., Debicka, M., Parylak, D., Kordas, L., 2014. The effect of a sandy soil amendment with municipal solid waste (MSW) compost on nitrogen uptake efficiency by plants. Eur $\mathrm{J}$ Agron. 54, 54-60. https://doi.org/10.1016/j.eja.2013.11.014

Wu, H., Zhao, Y., Long, Y., Zhu, Y., Wang, H., Lu, W., 2011. Evaluation of the biological stability of waste during landfill stabilization by thermogravimetric analysis and Fourier transform infrared spectroscopy. Bioresour. Technol. 102, 9403-9408. https://doi.org/10.1016/j.biortech.2011.07.029

Wu, S., Shen, Z., Yang, C., Zhou, Y., Li, X., Zeng, G., Ali, S., He, H., 2017. Effects of C/N ratio and bulking agent on speciation of $\mathrm{Zn}$ and $\mathrm{Cu}$ and enzymatic activity during pig manure composting. Int. Biodeterior.

https://doi.org/10.1016/j.ibiod.2016.09.016

Biodegradation. 119,

429-436.

Yadav, A., Suthar, S., Garg, V. K., 2015. Dynamics of microbiological parameters, enzymatic activities and worm biomass production during vermicomposting of effluent treatment plant sludge of bakery industry. Environ. Sci. Pollut. Res. 22, 14702-14709. https://doi.org/10.1007/s11356-015-4672-7 
Yadav, A., Gupta, R., Garg, V. K., 2013. Organic manure production from cow dung and biogas plant slurry by vermicomposting under field conditions. Int. J. Recycl. Org. Waste Agric. 2, 21. https://doi.org/10.1186/2251-7715-2-21

Yuvaraj, A., Karmegam, N., Thangaraj, R., 2018. Vermistabilization of paper mill sludge by an epigeic earthworm Perionyx excavatus: Mitigation strategies for sustainable environmental management. Ecol Eng. 120, 187-197. https://doi.org/10.1016/j.ecoleng.2018.06.008

Zhang, J., Lü, F., Shao, L., He, P., 2014. The use of biochar-amended composting to improve the humification and degradation of sewage sludge. Bioresour. Technol. 168, 252-258. https://doi.org/10.1016/j.biortech.2014.02.080 
2019-12-03

\section{Analysis and advanced characterization of municipal solid waste vermicompost maturity for a green environment}

Srivastava, Vaibhav

Elsevier

Srivastava V, Goel G, Thakur VK, et al., (2019) Analysis and advanced characterization of municipal solid waste vermicompost maturity for a green environment. Journal of Environmental Management, Volume 255, February 2020, Article number 109914

https://doi.org/10.1016/j.jenvman.2019.109914

Downloaded from Cranfield Library Services E-Repository 